\title{
Sex determination in the Giant fish of Amazon Basin, Arapaima gigas (Osteoglossiformes, Arapaimatidae), using laparoscopy
}

\author{
Carlos Riedel Porto CARREIROํㅗㅇ, Manuel Antônio de Andrade FURTADO-NETO², Pedro Eymard Campos \\ MESQUITA³, Tácito Araújo BEZERRA ${ }^{4}$
}

\begin{abstract}
The Giant of Amazon basin, pirarucu, Arapaima gigas, is the largest scaled freshwater fish in the world. Pirarucu cultivation has recently started, driven by the decline in natural populations and high market value. Currently, there are no reliable methods for sexual differentiation in this species other than direct examination of gonads, which requires dissection of specimens. A non-lethal and less invasive method for sexual identification is highly desirable in order to properly group broodstock for mating and offspring production. We utilized laparoscopic examination in anesthetized pirarucu to differentiate between male and female individuals. This method allowed for the observation and differentiation of the reproductive organs within an individual. Our results suggest that laparoscopy is an efficient method for sex differentiation in pirarucu causing minimal stress to the fish.
\end{abstract}

KEYWORDS: Arapaima gigas, Fish anesthesia, Laparoscopy, Sex differentiation.

\section{Determinação do sexo no peixe gigante da Bacia Amazônica, Arapaima gigas (Osteoglossiformes, Arapaimatidae), usando laparoscopia.}

O gigante da bacia amazônica, pirarucu, Arapaima gigas, é o maior peixe de escamas de água doce do mundo. O seu cultivo teve início recentemente motivado pelo declínio de suas populaçóes naturais em virtude do alto valor de sua carne no mercado. Não existem métodos para a diferenciação sexual nesta espécie, o único método é o exame direto das gônadas, o qual requer a dissecação do espécime. Um método para a identificação sexual é altamente desejável, a fim de selecionar grupos de reprodutores para o acasalamento e, portanto, a produção de progênie. A fim de diferenciar reprodutores machos de fêmeas, foi utilizado o exame laparoscópico em animais previamente anestesiados. Este método permitiu a observaçáo dos órgãos abdominais, incluindo gônadas, com grande precisão. Os resultados mostram que a laparoscopia é um método eficiente para a diferenciação do sexo em pirarucu e causam o mínimo de stress para os animais.

PALAVRA-CHAVE: Arapaima gigas, Anestesia, Laparoscopia, Diferenciação sexual.

\footnotetext{
1 Universidade Federal do Ceará - UFC. Departamento de Engenharia de Pesca - DEP. Avenida Mister Hull, s/n. - Pici - Fone: +55 (85) 3366.9723 - Fortaleza-CE. E-mail: carlos.riedel@yahoo.com

2 Instituto de Ciências do Mar - LABOMAR. Avenida da Abolição, 3207 - Meireles - Fortaleza - CE - Fone: +55 (85) 3366.7000. E-mail: mfurtado@ufc.br

${ }^{3}$ Centro de Pesquisas em Aquicultura Rodolpho von Ihering - CPA/DNOCS - Ombreira Direita, s/n. Pentecoste-CE. Fone: +55 (85)3352.1235 E-mail: pedro_mesquita@uol.com.br

${ }^{4}$ Centro de Pesquisas em Aquicultura Rodolpho von Ihering - CPA/DNOCS - Ombreira Direita, s/n. Pentecoste-CE. E-mail: tacitobezerra@bol.com.br
} 


\section{INTRODUCTION}

The Giant of Amazon basin, pirarucu, Arapaima gigas, is an air-breathing fish species native to the Amazon region and is one of the most economically and culturally most important species from the Brazilian-Amazonian ichthyofauna (Castello 2004; Andrade 2007). This species grows up to $3 \mathrm{~m}$ in length, weights up to $200 \mathrm{~kg}$, and is capable of living longer than 50 years (Saint-Paul 1986). The word pirarucu comes from the native Brazilian language tupi-guarani and which means "red fish", which is the color both sexes turn during the mating season. Males display an intense red color on abdominal scales whereas the red color is less intense in female specimens (Fontenele 1955; Chu-Koo et al 2008). However, this characteristic is not reliable as a means to differentiate sexes, and therefore, it is not used for this purpose.

Pirarucu cultivation efforts have recently started being driven primarily by the decline in natural populations and high market values. The aquaculture of this species represents an important management tool to minimize the effects of overharvest of wild populations (Alcantara 1991). In its natural habitat, pirarucu prey on many items including smaller fish, mollusks, insects and crustaceans (Imbiriba 2001; Cavero 2002). Under intensive culture, an initial feeding-training period is necessary in order to induce fish to capture pelleted food (Gandra 2002). In captivity, reproduction generally occurs in large earthen ponds where broodstock are grouped together at the beginning of the rainy season (January to May in Northeastern Brazil) (Fontenele 1955; Alcantara 1991).

Sexual dimorphism in pirarucu is a complex mechanism under the control of genetic, physiological and environmental factors (Devlin and Nagahama 2002). In most cultivated fish species, phenotypic sex is easily identified by observation of specific external characters such as scale coloration and the presence of genital papilla during early sexual maturation. Methods currently used for sexual identification of fish species include intra-ovarian biopsy, ultrasonography and endoscopy (Ortenburger et al. 1996; Kynard 2002; Wildhaber et al. 2005; Bryan et al. 2007; Hurvitz et al. 2007). For some fish species, DNA markers are available for sexual identification at the genetic level and in these cases the differentiation is based on distinguished gender-specific band patterns.

The use of anesthetics on fish is a common practice in laboratory research, especially for surgical proposes (Ross and Ross 2008). Anesthesia can reduce pain by blocking electric signals from periphery to both the spinal cord and brain (Craig 2003). Anesthetics are usually administered by immersion of fish in a diluted solution of anesthetic and the entrance point is predominantly via the gills. Pirarucu are an obligatory air-breathing fish, and the use of anesthesia by immersion can cause death by drowning. For this reason, we have developed a technique of anesthesia using chloroform with modified atmosphere (data not shown).

Pirarucu do not display significant external sexual dimorphism. To the best of our knowledge, no reliable method for sexual determination has been described for this species with the exception of minor morphological differences observed only in mature fish during the initiation of courtship behavior at approximately five years of age (Imbiriba 2001; Saavedra-Rojas et al. 2005; Chu-Koo et al. 2008). The absence of external characteristics for sexual determination has encouraged the development of practical and nondamaging techniques of internal examination of the gonads based on laparoscopy. This technique has been used in both the medical and veterinary fields to examine internal organs via insertion of an optical instrument into the body cavity through a small incision or the urogenital pore (Wildhaber et al. 2005; Ortenburger et al. 1996). The objective of our study was to assess the use of internal laproscopy as a means for determining gender of pirarucu.

\section{MATERIALS AND METHODS}

\section{Transport and acclimation}

Juvenile pirarucu ( $400 \pm 50 \mathrm{~g}$ and $40 \pm 5 \mathrm{~cm}$ ) acquired from a private company located in the city of Campo-Grande, Mato Grosso do Sul State, Brazil, were brought into the Rodolpho von Ihering Aquaculture Research Center, Pentecoste, Ceara, Brazil ( $3^{\circ} 48^{\prime} 42^{\prime \prime}$ S, 39 $\left.16^{\prime} 72^{\prime \prime} \mathrm{W}\right)$ in a specially adapted truck equipped with four TRANSFISH ${ }^{\circledR}$ units $(2,000$ liters each) connected to an aeration unit. The transportation period was approximately 96 hours and no mortality was recorded. Fish were acclimated and maintained in earthen ponds and fed ad libidum with pelleted commercial ration ( $42 \%$ protein and $12 \%$ fat) supplemented with whole grinded Nile tilapia, Oreochromis niloticus. Water temperature was maintained at 28 $\pm 2{ }^{\circ} \mathrm{C}$ all year around. After reaching three years of age, both length $(\mathrm{cm})$ and weight $(\mathrm{g})$ were measured and individuals were considered to be ready for laparoscopic examination.

\section{Anesthesia}

Previous studies conducted at Aquaculture Research Center Rodolpho von Ihering, Pentecoste, showed that evaporation of $3 \mathrm{~mL}$ chloroform solution in specimens of pirarucu $(30 \pm 3 \mathrm{~kg})$, causes loss of reflex and muscle relaxation. Based on this preliminary study we select ten 3 -year old fish $(30 \pm 3 \mathrm{~kg}$ and $150 \pm 18 \mathrm{~cm})$ for the anesthesia procedure. A plastic gas-mask has been specially adapted for the inhalation of chloroform. The gas-mask was tied to an air compressor for air supply. Each fish was individually placed on the examination table and anesthetized with the gasmask using chloroform. Time of induction and recovery was 
recorded. Only one concentration of chloroform was tested ( $3 \mathrm{~mL}$ in a 2 liters gas-mask supplied with atmospheric air).

\section{Laparoscopic examination}

Twelve 3-year old fish $(30 \pm 3 \mathrm{~kg}$ and $150 \pm 18 \mathrm{~cm})$ were randomly selected and kept in four concrete tanks (4 $\mathrm{m}^{3}$ ) under a raceway system (800\% water renovation/day). Based on the scale coloration, one male and one female were euthanized by immersion in ice-cold water and dissected in order to orient the insertion points for laparoscopy and determine the actual appearance of peritoneal organs, including the gonads. Each of the remaining 10 live specimens was placed on the examination table and anesthetized by inhalation of chloroform from an adapted gas-mask attached to an air supply, subsequently pirarucu received a $5 \mathrm{~mm}$ incision in the abdominal wall near the anal fin to possibility the laparoscopic procedure (Figure 1). The laparoscopy system consisted of a cystoscope sheath, $15 \mathrm{~cm}$ long and $5 \mathrm{~mm}$ in diameter $\left(\right.$ Karl Storz $\left.{ }^{\mathrm{TM}}\right)$, connected with an optic fiber light transmission, linked to a halogen cold light source and a mini video camera attached to a color monitor linked to a video recorder. The laparoscope was equipped with an air pump and an internal canal through which the abdominal wall could be inflated with air for a clear view. Observation and capture of digital images from internal organs including gonads were carried out. After the procedure, the incision was sutured, disinfected with powder sodium cloride, and individuals received implantable transponders for identification prior of being taken to a $4 \mathrm{~m}^{3}$ nursery-tank, containing $3 \%$ saline solution, were they rested for 3 days.
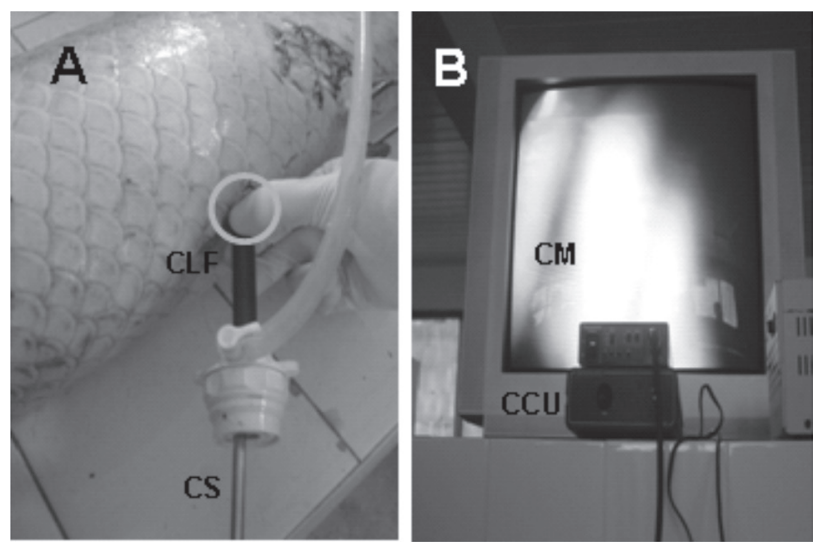

Figure 1 - Endoscopic examination through an abdominal incision. (A) Anesthetized "pirarucu". Circle show the position of the incision through which the trocater was inserted. (B) General aspect of laparoscopy system image. Laparoscopy system components: cystoscope sheath (CS), halogen cold light fountain (CLF) with fiberoptic light transmission cable, camera control unit (CCU) attached to a color monitor (CM).

\section{RESULTS AND DISCUSSION}

\section{Anesthesia}

A wide variety of compounds have been utilized to anesthetize fish: Tricaine Methanesulfonate (MS-222), Quinaldine (2-methylquinoline), Eugenol (4-allyl-2-methoxyphenol) and Carbon Dioxide (Browser 2002). Dosage for these compounds depends on the degree of anesthetization desired, the species, size, water temperature and water hardness (Keegan 2005; Zahl et al 2009). Generally, fish are maintained in an aquarium with anesthetic diluted solution and removed when they reach the desired level of anesthesia. Anesthetics are commonly taken into the system by the gills during respiration. As the pirarucu is an obligatory air-breathing fish; the use of anesthetics diluted in water can cause death by drowning due to the risk of not recovering the air-breathing reflex is very high. The anesthetic induction in pirarucu occured shortly after chloroform inhalation $(10 \pm 3 \mathrm{~s})$. The recovery time recorded for chloroform was $15 \pm 4$ min, which is much longer than the average of 3 to 5 min reported for many fish species (Pickering 1998). This study demonstrates the usefulness of chloroform-induced anesthesia in air-breathing fish. Further studies on this technique for pirarucu are highly suggested.

\section{Laparoscopic procedure}

Individual laparoscopic procedures lasted about 3 minutes per animal and clear digital images of both male and female gonads were obtained. The incisions made for the trocater introduction did not cause external bleeding and no any apparent damage to the internal organs was found by image inspection. Similar results were observed by Hernandez-Divers et al. (2004) for sturgeon, Acipenser gueldenstaedtii. Froehlich et al (1999) suggested that there is always a risk in any surgical procedure, but the risk is generally low with laparoscopy, as shown in sturgeons. The relationship between fish size and risk of mortality from the procedure may be an important consideration when using endoscopy on rare fish (Swenson et al. 2007). In the present study all specimens survived the laparoscopic surgical procedure. Our findings indicate the laparoscopy procedure to be an efficient, practical, and less stressful procedure for sex determination of pirarucu.

\section{Male and female differentiation}

It was possible to clearly differentiate male from female gonads based on image analysis for all examined subjects. Laparoscopic images from obtained from male fish showed a single testis with long, opaque, smooth, milky aspect located on the left side of the body close to the bladder and visible along the length of the body cavity (Figure 2A). Although 
the ability to differentiate fat from male testes was limited in endoscopic studies of shovelnose sturgeon (Wildhaber $e t$ al. 2005), male pirarucu testes could be differentiated from fat based on color. Images from females showed that a single fusiform ovary located along the abdominal cavity wall near the bladder. Through the laparoscopic process individual or multiple developing oocytes were easily identified by their semi-transparent green color. The presence of oocytes in different developmental stages was observed (Figure 2B).

\section{Scale color for sex determination}

Based on the intensity of the scale coloration, eight of the ten examined pirarucu were belived to be female, and two to be males. The laparoscopic examination revealed six female and four male, fact that leads us to believe that scale coloration patterns of sexually immature fish was not reliable as a characteristic for sexual differentiation. Chu-Koo et al. (2008) achieved 95\% efficiency in sex determination of 2.8 year-old pirarucu by using enzyme-immuno-assay while laparoscopy produced $100 \%$ accuracy (present work) by direct observation of oocytes, leading us to believe that laparoscopy is a reliable method for sex determination in immature pirarucu and can be considered a powerful tool in the management of aquaculture facilities.
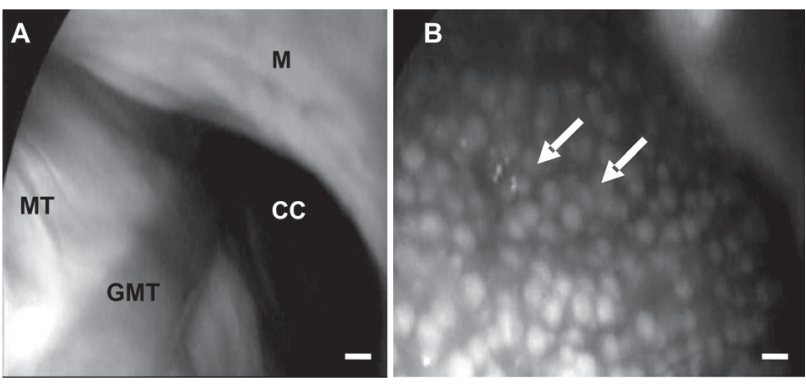

Figure 2 - Detail of laparoscopic examination of pirarucu gonads. A: male (CC) shows celomic cavity. (MT) muscular tissue and (GMT) gonadal male tissue. B: Female endoscopic view, white arrows show individual oocytes. Space bar: $1,0 \mathrm{~mm}$.

\section{CONCLUSION}

The use of chloroform as an anesthetic for pirarucu proved to be effective for allowing the complete and successful execution of the laparoscopy procedure. Scale color patterns were not effective on their own when used as a criteria for gender determination. The images generated by the laparoscopic procedure produced a high rate of accuracy for identification of both male and female gonads. Our study suggests that the use of laparoscopy in pirarucu culture is an efficient method for sex identification at early ages. The ability to observe intact gonads in anesthetized fish can provide an important management tool for fingerling production.

\section{ACKNOWLEDGMENTS}

To Dr. Nestor dos Santos Vieira Costa Neto for his technical assistance. C. R. P. Carreiro thanks to DNOCS (Departamento Nacional de Obras Contra as Secas) for use of laboratory facilities, CAPES (Coordenação de Aperfeiçoamento de Pessoal de Nível Superior) and FUNCAP (Fundação Cearanse de Apoio ao Desenvolvimento Científico e Tecnológico) for the scholarship provided.

\section{REFERENCES}

Alcantara, F. 1991. Observations on reproductive behavior of paiche, Arapaima gigas, in captivity. Folia Amazonica, 2: 165-168. (In Spanish with English abstract).

Andrade, J.I.A.; Ono, E.A.; Menezes, G.C.; Brasil, E.M.; Roubach, R.; Urbinati, E.C.; Tavares-Dias, M.; Marcon, J.L.; Affonso, E.G. 2007. Influence of diets supplemented with vitamins $C$ and $E$ on pirarucu (Arapaima gigas) blood parameters. Comparative Biochemistry and Physiology, 146: 576-580.

Bryan, B.J.L.; Wildhaber, M.L.; Papoulias, D.M.; Tillitt, D.E.; Annis, M.L. 2007. Estimation of gonad volume, fecundity, and reproductive stage of shovelnose sturgeon using sonography and endoscopy with application to the endangered pallid sturgeon. Journal Applied Ichthyology, 23: 411-419.

Castello, L. 2004. A Method to count pirarucu, Arapaima gigas: fishers, assessment, and management. North American Journal of Fish Management, 24: 379-389.

Cavero, B.A.S. 2002. Stocking density of pirarucu juvenile, Arapaima gigas (Cuvier, 1829) in cages with small volume. Dissertation, University of Amazonas, Manaus, Amazonas, Brazil. 51 p. (In Portuguese with English abstract).

Chu-Koo, F.; Dugué, R.; Aguilar, M.A.; Daza, A.C.; Bocanegra, F.A.; Veintemilla, C.C.; Duponchelle, F.; Renno, J.F.; Tello, S.; Nuñez, J. 2008. Gender determination in the Paiche or Pirarucu (Arapaima gigas) using plasma vitellogenin, 17b-estradiol, and 11-ketotestosterone levels. Fish Physiology and Biochemistry, 35: 125-136.

Craig, A.D. 2003. Pain mechanisms: labeled lines versus convergence in central processing. Annual Review of Neuroscience, 26: 1-30.

Devlin, R.H.; Nagahama, Y. 2002. Sex determination and sex differentiation in fish: an overview of genetic, physiological, and environmental influences. Aquaculture, 208: 191-364.

Fontenele, O. 1955. Contribution to the knowledge of pirarucu, Arapaima gigas (Cuvier) in captivity (Actinopiterygii, Osteoglossidae). Departamento Nacional de Obras Contra as Secas (DNOCS), Fortaleza, Ceara, Brazil. 16p. (In Portuguese).

Froehlich,F.; Gonvers, J.J.; Dubois, R.W.; Burnand, B. 1999. Appropriateness of gastrointestinal endoscopy: risk of complications. Endoscopy, 31: 684-686.

Gandra, A.L. 2002. Food Frequency Study of the pirarucu, Arapaima gigas (Cuvier, 1829). Dissertation, University of Amazonas, Manaus, Amazonas, 36 p. (In Portuguese with English abstract). 
Hernandez-Divers, S.M.; Dover, S.R. 2004. Endoscopic sex determination and gonadal manipulation in Gulf of Mexico sturgeon (Acipenser oxyrinchus desotoi). Journal of Zoology and Wildlife Medicine,_35: 459-470.

Hurvitz, A.; Jackson, K.; Degani, G.; Levavi-Sivan, B. 2007. Use of endoscopy for gender and ovarian stage determinations in Russian sturgeon (Acipenser gueldenstaedtii) grown in aquaculture. Aquaculture, 270: 158-166.

Imbiriba, E.P. 2001. Potential of farm fishing pirarucu, Arapaima gigas, in captivity. Acta Amazonica. 31: 299-316. (In Portuguese with English abstract).

Keegan , R. D. , 2005. Inhalant anesthetics: The Basics. In: R.D. Gleed (ed.). Recent Advances in Veterinary Anesthesia and Analgesia: pets. Ithaca : International Veterinary Information Service (www.ivis.org); No. A1402.1005 document. 12 pp.

Kynard, B.; Kieffer, M. 2002. Use of a borescope to determine the sex and egg maturity stage of sturgeons and the effect of borescope use on reproductive structures. Journal of Applied Ichthyology, 18: $505-508$.

Ortenburger, A.I,; Jansen, M.E.; Whyte, S.K. 1996 - Nonsurgical videolaproscopy for determination of reproductive status of the arctic charr. Canadian Veterinary Journal, 37: 96-100.

Pickering, A.D. 1998. Stress responses of farmed fish. In K. D. Black and A. D. Pickering (eds.). Biology of farmed fish. Sheffield Academic Press, Sheffield, U.K. pp. 222-255
Ross, L.G.; Ross, B. 2008. Anaesthetic and sedative techniques for aquatic animals. Oxford: Blackwell Science. 3rd edition, $236 \mathrm{p}$.

Saavedra-Rojas, E.; Quintero-Pinto, L.; Landines Parra, M. 2005. Reproductive aspects: Biology and cultivation of pirarucu, Arapaima gigas (Schinz, 1822) (Pisces: Arapaimidae): INCODER-UNC, Bogota, Colômbia, 109 p. (in Spanish).

Saint-Paul, U. 1986. Potential for aquaculture of South American freshwater fishes: a review. Aquaculture, 54: 205-240

Swenson, E.A.; Rosenberger, A.E.; Howell, P.J. 2007. Validation of endoscopy for determination of maturity in small salmonids and sex of mature individuals. Transactions of the American Fisheries Society, 136: 994-998.

Wildhaber, M.L.; Papoulias, D.B.; DeLonay, A.J.; Tillitt, D.E; Bryan, J.L; Annis, M.L; Allert, J.A. 2005. Gender identification of shovelnose sturgeon using ultrasonic and endoscopic imagery and the application of the method to pallid sturgeon. Journal of Fish Biology, 67:114-132.

Zahl, I.H.; Kiessling, A.; Samuelsen, O.B.; Hansen, M.K. 2009 - Anaesthesia of Atlantic cod (Gadus morhua) - effect of re-anaesthetic sedation, and importance of body weight, temperature and stress. Aquaculture, 295: 52-59.

Recebido em 14/06/2010

Aceito em 05/08/2010 